\title{
Modelling Uncertainty of Vehicular Emissions Inventory: A Case Study of Ireland
}

\author{
Shreya Dey, Brian Caulfield, Bidisha Ghosh
}

\author{
Please cite as: Dey, S., Caulfield, B., Ghosh, B. Modelling \\ Uncertainty of Vehicular Emissions Inventory: A Case Study of \\ Ireland, Journal of Cleaner Production, 2019, Vol 213, pp1115-1126
}

\begin{abstract}
National Emission Inventory is a comprehensive and detailed estimate of air pollutants from emissions sources and is used to determine the status to reach targets, to develop new strategies and policies, in impact assessment and projections. It is recommended by the European Commission in its National Emissions Ceilings Directive and by Intergovernmental Panel on Climate Change in its guidelines for National Greenhouse Gas Inventories that NEI reports must include information on uncertainties. COPERT is a road transport emission modelling software tool used in preparing emission inventory and research in many countries. This paper aims to estimate the uncertainties associated with COPERT (v.5.1) outputs by varying the input parameters such as temperature, speed, relative humidity, mileage share and trip length, whose values are either not accurately available or average of which is considered in the quantification of vehicular emission. The emission levels calculated using COPERT 5 due to parameter variations were used to characterize the uncertainty associated with the passenger car emission inventory in terms of their probability distributions. Passenger car emission inventories were prepared separately for Greater Dublin Area (GDA) which has more population and car density than the rest of the country, to find out the emissions share compared to Ireland. The results indicate that emissions levels are very sensitive to average trip length and average speed and therefore, require precise consideration. However, the results revealed that rural and highway driving shares do not have a considerable impact on overall emission levels. The levels of possible variations are more in $\mathrm{CO}$, VOC and NMVOC emission estimates than other
\end{abstract}


pollutants. GDA has $48 \%$ and $50.37 \%$ shares of $\mathrm{CO}_{2}$ and $\mathrm{NOx}$ respectively compared to overall levels in the country. This shows that the uncertainty associated with the model outputs will have a pronounced effect on GDA in policy settings and emission reduction strategies.

Keywords: Air pollution; emission inventory; COPERT 5; uncertainty modelling; sensitivity analysis; 


\section{Introduction}

Transport is a major air polluting sector; several targets are now set to reduce the emissions. The transport sector accounts for $23.2 \%$ of the overall greenhouse gas emissions in Europe (Eurostat, 2014). Whereas in Ireland, the emission share from transport is about $20 \%$ (EPA, 2017). Over the past 15 years, the number of cars in Ireland has increased by 43\% (CSO, 2014; DTTaS, 2016). Also, the transport sector is the largest energy-consuming sector in Ireland, with a share of $42 \%$ in 2015 (SEAI, 2015). Road transport is responsible for the emissions of various regulated and unregulated pollutants (Gkatzoflias et al., 2012). Major parts of carbon monoxide (CO) and carbon dioxide $\left(\mathrm{CO}_{2}\right)$ emissions result from passenger cars (Fameli and Assimakopoulos, 2015). The emission from on-road vehicle account for $95.8 \%$ of the overall transport emissions in Ireland (EPA, 2017). The impact of air pollution is higher in urban areas due to higher vehicle density and in urban areas, the main source of air pollution is road transportation. A large percentage of urban populations are exposed to air pollution which is higher than the European standard and WHO Air Quality Guidelines (EEA, 2016).

National Emission Inventory (NEI) is the main component of air quality management and used in air pollution control programme, emission projections, emission prevention and control measures, quantification of actual emissions, development of policies to prevent and control emissions and environmental impact assessment (USEPA, 2017; Yan et al., 2014; ACAP, 2007; Souza et al., 2013). Therefore, it is very important to calculate air pollutant emission levels accurately. The quality of the inventory can significantly be improved by using detailed input data and reducing any uncertainty (Kouridis et al., 2010). Emission levels are affected by various factors associated with the road (road surface condition, gradient, pavement type etc.), vehicle (engine size, fuel type, technology class etc.), environment (relative humidity, temperature etc.) and traffic (speed, acceleration etc.) (Demir et al., 2011). Most of the vehicular emissions models utilize these factors in some form. But models are imperfect abstractions of reality and due to lack of availability of precise input data, all outputs are subject to imprecision and uncertainty (Loucks et al., 2005). Uncertainty estimation is very important to provide information about the sources of uncertainty and their potential reduction (Borrego et al., 2008). One component of uncertainty related to model estimates is the uncertainty related to input 
data. Therefore, it is recommended that information on uncertainty must be included while reporting the national emissions inventory (EEA, 2016; IPCC, 2006). Uncertainty in emissions estimates has been assessed by several researchers (Kioutsioukis et al., 2004; Saikawa et al., 2017; Notte et al., 2018).

Sensitivity analysis, on the other hand, helps to build confidence in the model by studying the uncertainties that are often associated with parameters in models (Yao et al., 2014). A sensitivity analysis combined with uncertainty analysis can help to understand if the current state of knowledge about the input data and related uncertainties is enough to take the decision (Kioutsioukis et al., 2004). Thereby, it helps to identify which data or parameters need resource allocation to achieve the desired level of confidence on the results (Kioutsioukis et al., 2004). Several researchers have carried out a sensitivity analysis of emission modelling parameters (Choi et al., 2010; Yao et al., 2014; Singh et al., 2012; Garcia et al., 2013; Bell et al., 2013).

COPERT (COmputer Programme to calculate Emissions from Road Transport) is used by 22 European member states for official submission of road transport inventories (Kioutsioukis et al., 2004). COPERT is an average speed model and can estimate emissions of all major regulated and unregulated air pollutants such as, $\mathrm{CO}_{2}, \mathrm{CO}, \mathrm{NO}_{\mathrm{x}}$, VOC (Volatile Organic Compound), Particulate Matter $\left(\mathrm{PM}_{2.5}\right.$ and $\left.\mathrm{PM}_{10}\right)$, Ammonia $\left(\mathrm{NH}_{3}\right)$, Sulphur dioxide $\left(\mathrm{SO}_{2}\right)$, Nitrus Oxide $\left(\mathrm{N}_{2} \mathrm{O}\right)$, Methane $\left(\mathrm{CH}_{4}\right)$ produced by different on-road vehicle categories, like passenger cars, light commercial vehicles, heavy duty trucks, buses, motorcycles, and mopeds (Kouridis et al., 2014). Three types of roadway driving modes can be considered in COPERT (urban, rural and highways) and include several important emission factors (EFs) such as, cold over hot ratio, ambient temperature, vehicle use, mileage, fuel characteristics. In previous studies (Achour et al. 2011; Berkowicz et al., 2006; Kousoulidou et al. 2010), it was reported that COPERT 4 underestimates $\mathrm{NO}_{\mathrm{X}}$. However, COPERT 5 has modified $\mathrm{NO}_{\mathrm{X}}$ emission factors.

COPERT has popularly been used by several researchers in Ireland (Caulfield, 2009; Brady and O‘Mahony, 2011; Alam et al., 2015; Doorley et al., 2015; Dey et al., 2017) and other European 
countries (Ong et al., 2011; Borge et al., 2012; Pouliot et al., 2012; Fameli and Assimakopoulos, 2015). GDA is defined as Dublin and the surrounding counties of Fingal, Dun Laoghaire-Rathdown, South Dublin, Kildare, Wicklow and Meath (Brady and O`Mahony, 2011). GDA consists of about $40 \%$ of Ireland's population $(\mathrm{CSO}, 2011)$ whereas the passenger car share of GDA is about $50 \%$ of overall Ireland (SIMI, 2015). The more densely populated areas are mainly located within GDA (CSO, 2016). Dublin and Only three of the top 20 most densely populated areas are located outside GDA (CSO, 2012).

The most updated version of COPERT i.e. COPERT 5, released in late 2016 (EMISIA, 2017), has been used in this study. COPERT 5 requires detailed meteorological, activity and fleet data. There are parameters whose values are not accurately measured and/or average values are considered in estimating vehicular emission in Ireland. Considering the importance of emission inventory, this paper examines the effect of these parameters, like temperature, Relative Humidity (RH), speed, mileage share and trip length on emission levels. The study gives insight into the sensitivity of emission levels of major air pollutants to those parameters and indicates the potential of reducing emission by controlling some of those parameters.

In this paper, the emission levels of $\mathrm{CO}_{2}, \mathrm{CO}, \mathrm{NOx}, \mathrm{PM}_{2.5}, \mathrm{PM}_{10}$, VOC, NMVOC (Non-methane Volatile Organic Compound), and $\mathrm{N}_{2} \mathrm{O}$ have been reported by varying temperature, average speed, $\mathrm{RH}$, driving mode share and average trip length. These parameters are varied one at a time, as well as two or more parameters, had been varied simultaneously. Meteorological parameters, i.e. temperatureRH interaction and activity related parameters, i.e. speed, trip length and mileage share interactions were examined. The individual effect of some of these parameters on the reduction of emission levels was studied (Fameli and Assimakopoulos, 2015; Vanhulsel et al., 2014; Andrias et al., 1993) in other countries. The present study extends their work by considering an exhaustive set of all parameters which lack precision, parameter interaction and a detailed sensitivity analysis. The level of variations in emission estimates with the variations in parameters shows the level of possible uncertainty in model outputs. Finally, statistical analysis was carried out to understand the nature of uncertainty in COPERT 5 outputs and damage costs to parameter variations. 


\section{Data description}

In this section, the data used in this research and their respective sources have been described. The level of availability and the extent of their variability have also been described. COPERT follows tier 3 methodology which calculates emissions based on detailed input data. Table 1 shows the necessary input parameters for COPERT 5 and their required level of disaggregation along with their level of availability and sources. Input data like fuel/energy consumption and kilometres travelled can be derived from national car testing results. Whereas, the fleet configuration can be accurately obtained from the national vehicle registration database. Information on temperature, relative humidity are recorded in monitoring stations across the country but an average value is used in emission calculation for the entire country. Parameters, such as average trip length, average speed, and driving mode share are not measured at a detailed level and can significantly vary.

\section{Table 1}

COPERT 5 input data, their sources and their level of availability in Ireland.

\begin{tabular}{|c|c|c|c|}
\hline Input data & Required level & Source & $\begin{array}{c}\text { Measured/not } \\
\text { measured }\end{array}$ \\
\hline $\begin{array}{l}\text { Fuel consumption } \\
(\mathrm{TJ})\end{array}$ & Total for each fuel type & $\begin{array}{l}\text { Sustainable Energy Authority of } \\
\text { Ireland (SEAI, 2016) }\end{array}$ & Available \\
\hline $\begin{array}{l}\text { Fleet } \\
\text { configuration }\end{array}$ & $\begin{array}{l}\text { Disaggregated to each } \\
\text { fuel-engine size- } \\
\text { technology } \\
\text { combination }\end{array}$ & $\begin{array}{l}\text { Motorstats: The official statistics of the } \\
\text { Irish Motor Industry (SIMI, 2016). } \\
\text { Department of Transport, Tourism and } \\
\text { Sport (DTTaS, 2016). }\end{array}$ & Available \\
\hline Trip length (km) & $\begin{array}{l}\text { Trip length for the } \\
\text { vehicle type under } \\
\text { calculation }\end{array}$ & National Travel Survey (CSO, 2014) & $\begin{array}{l}\text { Yearly average } \\
\text { reported }\end{array}$ \\
\hline Temperature $\left({ }^{\circ} \mathrm{C}\right)$ & $\begin{array}{l}\text { Monthly minimum and } \\
\text { maximum temperature }\end{array}$ & $\begin{array}{l}\text { MET Eireann: The Irish } \\
\text { Meteorological Service Online (2016) }\end{array}$ & $\begin{array}{l}\text { Measured at } \\
\text { monitoring stations }\end{array}$ \\
\hline $\begin{array}{l}\text { Relative Humidity } \\
(\%)\end{array}$ & Monthly humidity & $\begin{array}{l}\text { MET Eireann: The Irish } \\
\text { Meteorological Service Online (2016) } \\
\text { World Weather and Climate } \\
\text { Information }(2016)\end{array}$ & $\begin{array}{l}\text { Measured at } \\
\text { monitoring stations }\end{array}$ \\
\hline Driving share $(\%)$ & $\begin{array}{l}\text { Disaggregated to } \\
\text { Urban, Rural, Highway }\end{array}$ & Brady and O`Mahony (2011) & Not measured \\
\hline $\begin{array}{l}\text { Average speed } \\
(\mathrm{kmph})\end{array}$ & $\begin{array}{l}\text { Disaggregated to } \\
\text { Urban, Rural, Highway }\end{array}$ & Road Safety Authority (2015) & $\begin{array}{l}\text { Average free speed } \\
\text { measured }\end{array}$ \\
\hline $\begin{array}{l}\text { Average annual } \\
\text { mileage }(\mathrm{km})\end{array}$ & $\begin{array}{l}\text { Disaggregated to each } \\
\text { fuel- engine size- } \\
\text { technology } \\
\text { combination }\end{array}$ & $\begin{array}{l}\text { CSO (2014) } \\
\text { SEAI (2013) }\end{array}$ & Measured \\
\hline
\end{tabular}


The monthly average minimum and maximum temperatures are presented in Fig. 1. The mode (the most frequently occurring data) of the daily minimum and maximum temperature gaps are also shown in Fig. 1.

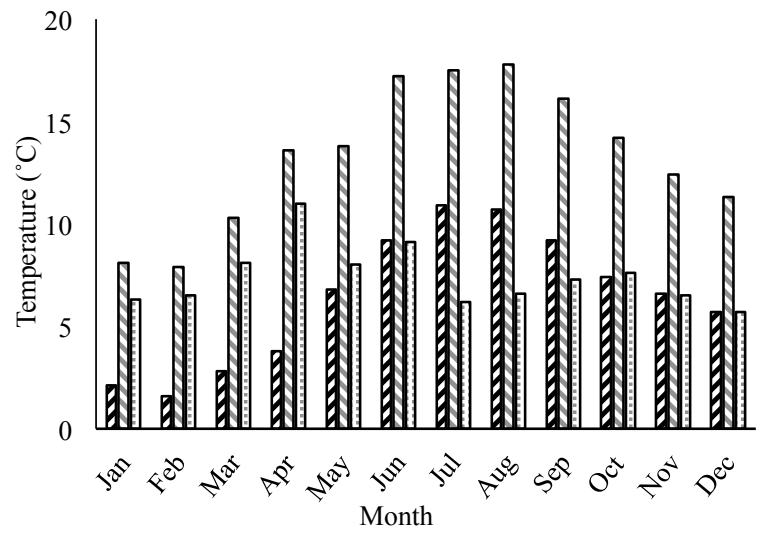

Minimum temperature $\left({ }^{\circ} \mathrm{C}\right)$

Maximum temperature $\left({ }^{\circ} \mathrm{C}\right)$

aMode of the temperature differences $\left({ }^{\circ} \mathrm{C}\right)$

Fig. 1. Monthly average minimum, maximum and mode of the temperature differences at the base scenario.

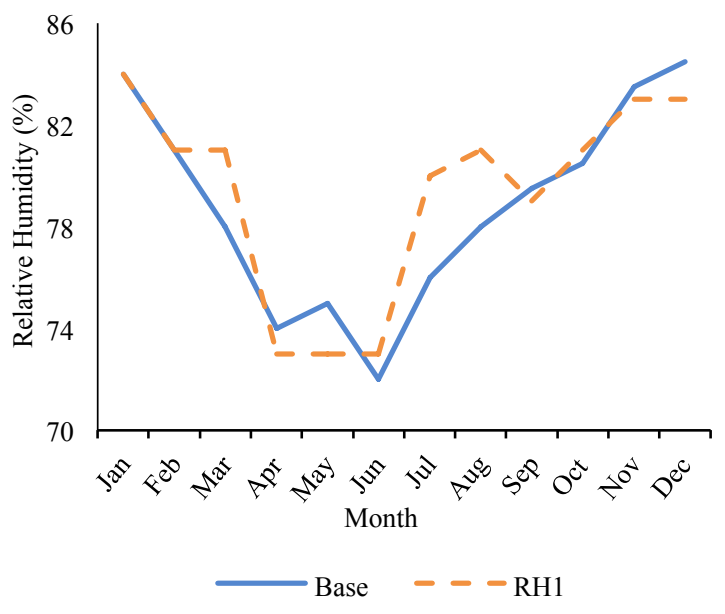

Fig. 2. Monthly average relative humidity (\%) at the base scenario.

The fleet data are mainly extracted from the Society of Irish Motor Industry (SIMI, 2016) and DTTaS (2016). The detailed division of fleet data with respect to engine classes i.e. Small $(<1.4 \mathrm{~L})$, medium (1.4-2.0 L) and large (>2.0L), fuel type and technology classes (Euro 1, Euro 2 etc.) have been shown in Fig. 3.

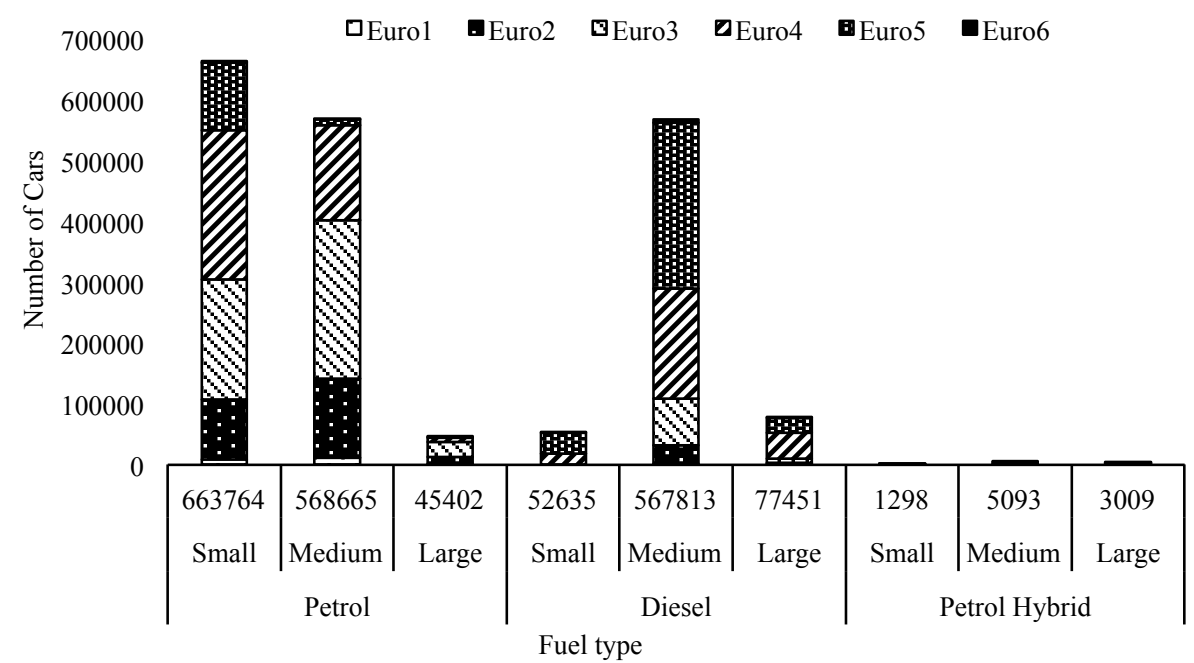

Fig. 3. Passenger car fleet composition by fuel type, engine size and technology class on 2015. 
For diesel cars, the medium sized engines are significantly high than other engine sizes. Mileage share for the base case was assumed to be $16 \%, 8 \%, 76 \%$ for urban, rural and highway for GDA and the same shares for Ireland is taken as $30 \%, 50 \%, 20 \%$ respectively. These values were taken from the previous research carried out in Ireland (Brady and O`Mahony, 2011). The average urban driving speed for the base case was taken as $40 \mathrm{kmph}$, for rural as $60 \mathrm{kmph}$ and highway as $100 \mathrm{kmph}$.

\section{Methodology}

This section presents the basic concepts of COPERT 5 model in estimating emission levels resulting from road transport, the methodology followed in developing national inventory using COPERT 5 and in designing possible scenarios to capture the effect of variation of input parameters on emission levels.

\subsection{COPERT Algorithm}

Depending on the extent of data availability, three different approaches can be used to calculate emissions (EEA, 2016). The methods are named as Tier 1, Tier 2 and Tier 3 approach. COPERT 5 follows the Tier 3 approach which uses a combination of firm technical data, such as, emission factors and detailed activity corresponding to each technology class. COPERT 5 uses the improved methodology in terms of updated $\mathrm{NO}_{\mathrm{X}}$ emission factors for diesel passenger cars and light commercial vehicles. The following set of equations are used to calculate the total emissions in the COPERT (Ntziachristos and Zissis, 2014),

$$
\mathrm{E}_{\text {total }}=\mathrm{E}_{\mathrm{hot}}+\mathrm{E}_{\text {cold }}
$$

where $\mathrm{E}_{\text {total }}$ is the total emissions of a pollutant; $\mathrm{E}_{\mathrm{hot}}$ is the hot exhaust emissions that occur when the engine and emission control system reach their typical operating temperature and $E_{\text {cold }}$ is the cold start emissions discharged during transient thermal engine operation, i.e. when engines and catalysts are not fully warmed up. The hot exhaust emission is calculated using the following equation, 


$$
E_{\text {hot; }, \mathrm{t}, \mathrm{r}}=\mathrm{N}_{\mathrm{t}} * \mathrm{M}_{\mathrm{t}, \mathrm{r}} * \mathrm{EF}_{\text {hot } ; \mathrm{p}, \mathrm{t}, \mathrm{r}}
$$

where, $E_{\text {hot } p, t, r}$ is the hot exhaust emissions of the pollutant $p$, produced in the period concerned by vehicles of technology $t$ driven on roads of type $r ; N_{t}$ is the number of vehicles of technology $t$ in the period concerned; $M_{t, r}$ is the mileage per vehicle driven on roads of type $r$ by vehicles of technology $t$; $E F_{\text {hot; }, t, r}$ is the EF for pollutant $p$, relevant for the vehicle technology $t$, operated on roads of type $r$. Cold-start emissions are introduced into the calculation as additional emissions per $\mathrm{km}$ using the following formula,

$$
\mathrm{E}_{\text {cold; } \mathrm{p}, \mathrm{t}}=\beta_{\mathrm{p}, \mathrm{t}} * \mathrm{~N}_{\mathrm{t}} * \mathrm{M}_{\mathrm{t}} * \mathrm{EF}_{\text {hot } ; \mathrm{p}, \mathrm{t}} *\left(\mathrm{e}^{\mathrm{cold}} / \mathrm{e}^{\mathrm{hot}} \mid \mathrm{p}, \mathrm{t}-1\right)
$$

where, $E_{\text {cold; }, t}$ is the cold-start emissions of pollutant $p$ (for the reference year), produced by vehicle technology $t ; \beta_{p, t}$ is the fraction of mileage driven with a cold engine or the catalyst operated below the light-off temperature for pollutant $p$ and vehicle technology $t ; M_{t}$ is total mileage per vehicle in vehicle technology $t ; e^{\text {cold }} /\left.e^{\text {hot }}\right|_{p, t}$ is cold/hot emission quotient for pollutant $p$ and vehicles of technology class $t$.

3.2. National Emission Inventory, Ireland (2015)

In order to calculate emissions inventory, passenger car fleet data were extrcted from SIMI (2016). Three fuel categories have been considered, petrol, diesel and petrol hybrid. A petrol-hybrid vehicle uses both internal combustion engine using gasoline and electric motor to power the vehicle. Fleet data were sorted into three engine classes, $<1.4 \mathrm{~L}, 1.4-2.0 \mathrm{~L}$, and 2.0L. A detailed description of the fleet composition is shown in section 2.

Average Annual Mileage (AAM) values for each engine size class varying from $<900 \mathrm{cc}$ to $>3,000 \mathrm{cc}$ (with 100 cc interval) for each year from 2000-2011 for diesel and petrol passenger cars were obtained from SEAI (2013) database provided by the National Car Testing services. These mileages were grouped into three engine categories, i.e. $<1.4 \mathrm{~L}, 1.4-2.0 \mathrm{~L}$ and $>2.0$ listed in COPERT 5 for petrol and diesel cars. These AAMs for each class were then extrapolated using linear regression to get the AAM for 2015, as shown in Fig. 4. 

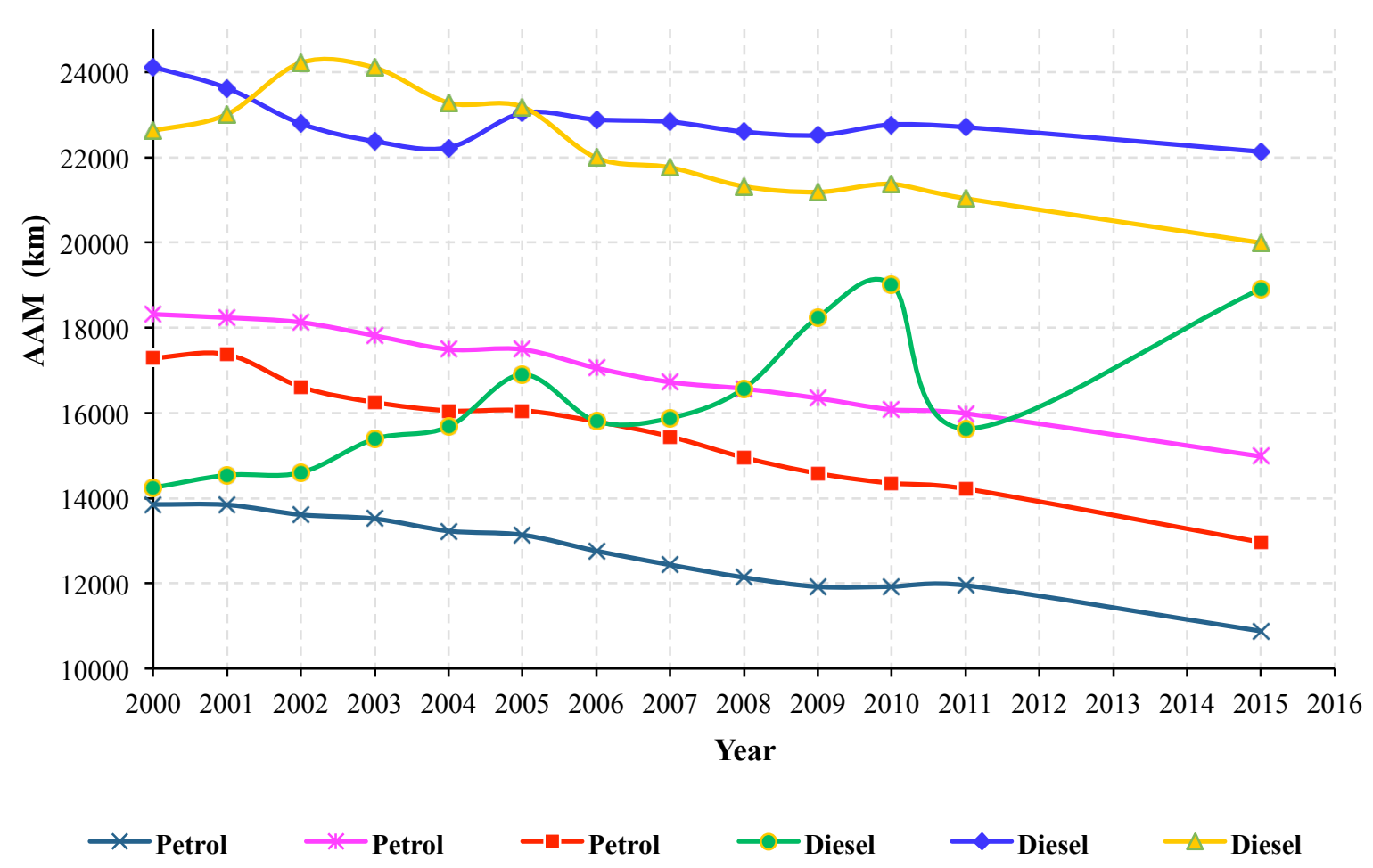

Fig. 4. Disaggregated AAM (km/year) of passenger cars for 2000-2011 (SEAI, 2013) and 2015 (extrapolated)

The $\mathrm{R}^{2}$ values obtained are shown in Table 2. $\mathrm{R}^{2}$ or coefficient of determination is a measure of how well observed outcomes are replicated by the model. It can be observed from Fig. 4 that AAM has a decreasing trend which is because of the increasing rate of car ownership in Ireland (SEAI, 2014).

Table 2. Coefficient of determination $\left(R^{2}\right)$ values from the linear regression of AAMs

\begin{tabular}{lccc}
\hline Fuel type & Small & Medium & Large \\
\hline Petrol & & & \\
\hline Diesel & 0.96 & 0.99 & 0.97 \\
\hline
\end{tabular}

The goodness of fit of mileage estimates of diesel vehicles is not as good as petrol vehicles. Alam et al. (2015) identified that diesel PCs do not show high co-relations with economic activity data which can be linked to more diesel powered vehicle use in recent years due to the introduction of $\mathrm{CO}_{2}$ emissions based tax policy in Ireland. Annual mileage is an important parameter in determining emission levels. In order to examine the effect of inaccuracy in AAM consideration, COPERT was also run for the base scenario with AAM aggregated over all the engine size and fuel types. Aggregated AAM of all the cars in 2015 was obtained in the same way, i.e. by extrapolating 12-year's (2000-2011) aggregated AAM data. This showed a good fit with an $\mathrm{R}^{2}$ value of 0.969 . As mentioned earlier, emissions were calculated using COPERT 5 for eight pollutants $\left(\mathrm{CO}, \mathrm{CO}_{2}, \mathrm{NO}_{\mathrm{X}}, \mathrm{PM}_{2.5}, \mathrm{PM}_{10}\right.$, 
VOC, NMVOC, and $\mathrm{N}_{2} \mathrm{O}$ ) in tonnes per year. Passenger car emissions inventory was then prepared for GDA which has the largest share of population and automobile density in Ireland. The fleet data for GDA were also extracted from the official statistics of the Irish Motor Industry (SIMI, 2016).

\subsection{Sensitivity Analysis}

Emission levels are affected by several parameters related to road, vehicle, environment, and traffic. Where the traffic data such as fleet composition can be obtained from the national database and sorted as per the requirement, meteorological and activity data are not accurately available or not possible to measure or spatially variable. In order to test the sensitivity of the model outputs to the input parameters and quantify the possible uncertainty associated with the model estimates, input parameters related to weather and activity were examined. Two approaches were taken to assess this. At first, those input parameters were varied individually (one factor at a time). Then based on one factor at a time analysis, more sensitive parameters were identified and two factors were varied simultaneously to examine the impact of factor interaction on emission levels. The scenarios are described in the following sections.

\subsubsection{One factor at a time}

In this scenario, the effect of single factor variation on emission levels was assessed. The input parameters considered are temperature, $\mathrm{RH}$, average speed, mileage share, and average trip length. This provides the knowledge and understanding of the sensitivity of the emission levels of the major air pollutants to those parameters. A summary of the designed scenarios has been shown in Table 3 . The details of the base scenario, designed scenarios and the approach followed to design the scenarios are described later in the following subsections.

\section{Table 3}

Summary of the designed scenarios.

\begin{tabular}{lll}
\hline Parameter & Base scenario & Description of the tested scenario \\
\hline Temperature & Monthly average minimum & $-\mathrm{T} 1:$ Extreme minimum and extreme maximum \\
(T) & and maximum & $-\mathrm{T} 2$ : Extreme minimum among recorded temperatures as \\
& monthly minimum and extreme minimum plus mode of the \\
& daily temperature variations in that month as monthly \\
& maximum \\
& $-\mathrm{T} 3:$ Extreme maximum among recorded temperatures as \\
& monthly maximum and extreme maximum minus mode of \\
& the daily temperature variations in that month as monthly \\
\hline
\end{tabular}




\begin{tabular}{lll} 
& & minimum \\
\hline $\begin{array}{l}\text { Relative } \\
\text { Humidity } \\
(\mathrm{RH})\end{array}$ & Monthly average & -RH1: Mode of the monthly relative humidity \\
\hline Speed (S) & Average speeds on & \\
& Urban(40), Rural(60), & -S1: Speed limits on Urban(50), Rural(80) and \\
& Highway(100) & -S2: Average lower speeds on Urban(25), Rural(50) and \\
& & Highway $(80)$ \\
\hline Mileage & Urban:Rural:Highway as & -MS1: Urban:Rural:Highway as $30 \%: 40 \%: 30 \%$ \\
share (MS) & $30 \%: 50 \%: 20 \%$ & \\
& & -MS2: Urban:Rural:Highway as $40 \%: 40 \%: 20 \%$ \\
& & -MS3: Urban:Rural:Highway as $50 \%: 40 \%: 10 \%$ \\
\hline Trip length & $15.1 \mathrm{~km}$ & - TL1: $6.0 \mathrm{~km}$ \\
$(\mathrm{TL})$ & & -TL2: $9.1 \mathrm{~km}$ \\
& & -TL3: $12.1 \mathrm{~km}$ \\
& & -TL4: $18.1 \mathrm{~km}$ \\
& & -TL5: $21.1 \mathrm{~km}$ \\
& & -TL6: $24.2 \mathrm{~km}$ \\
\hline
\end{tabular}

- Temperature (T): COPERT requires monthly minimum and maximum temperatures for emission calculation. While calculating the emission levels for a whole country, the average of the recorded monthly maximum and minimum temperatures of all the stations are considered. But this may result in under- or over-estimation of emissions if some parts of a country experience significantly higher or lower temperature compared to other areas. To examine the level of variability in emission estimates as a result of temperature variations, three scenarios were designed in addition to the base scenario which presents the emission levels in 2015 taking temperatures as monthly averages of all the stations. The scenarios were designed such that the possible variation is captured. The scenarios were designed based on the extreme minimum, extreme maximum and daily temperature gaps between minimum and maximum. Further, the mode of the daily temperature gaps was considered which reflects the variation of daily temperature which is mostly occurring. It may be more realistic to capture the gap between the minimum and maximum temperature by considering the mode of the temperature differences. The designed temperature scenarios are described as follows,

Temperature scenario 1 (T1),

$T_{i, \min }=\left\{T_{i}\right\}_{\min }$

$T_{i, \max }=\left\{T_{i}\right\}_{\max }$

$i=$ Month, i.e. Jan, Feb, Mar.........Nov, and Dec.

$T_{i, m i n}=$ Minimum temperature for emission calculation in month $i$ 
$T_{i, \max }=$ Maximum temperature for emission calculation in month $i$

$\left\{T_{i}\right\}_{\min }=$ Minimum of all the recorded temperatures at the monitoring stations in month $i$

$\left\{T_{i}\right\}_{\max }=$ Maximum of all the recorded temperatures at the monitoring stations in month $i$

Temperature scenario 2 (T2),

$T_{i, \min }=\left\{T_{i}\right\}_{\min }$

$T_{i, \max }=\left\{T_{i}\right\}_{\min }+d_{i, \operatorname{mode}}$

$d_{i \text { mode }}=$ Mode of the temperature gaps (shown in Fig. 1) between maximum and minimum in month $i$ Temperature scenario 3 (T3),

$T_{i, \min }=\left\{T_{i}\right\}_{\max }-d_{i, \operatorname{mode}}$

$T_{i, \max }=\left\{T_{i}\right\}_{\max }$

- Relative Humidity (RH): Apart from the base case RH values, which is the average monthly $\mathrm{RH}$ of all the monitoring stations, another RH scenario was considered taking the mode of the monthly $\mathrm{RH}$ of all the monitoring stations. Monthly $\mathrm{RH}$ and mode of the monthly $\mathrm{RH}$ recorded in all the stations are shown in Fig. 2.

- Speed (S): COPERT requires average speeds in urban, rural and highway driving conditions. Speed information for these categories is not precisely found. Speed is one of the major parameters influencing vehicular emissions, therefore, it is very important to see the possible variation in speed. In this study, the base scenario considers average speed for urban, rural, and highway as $40 \mathrm{kmph}, 60 \mathrm{kmph}$, and $100 \mathrm{kmph}$ respectively (Road Safety Authority, 2015; Alam et al., 2015). These speed values are taken based on the free speed survey. To see the level of variability two extreme conditions were tested, one scenario (S1) considers the posted speed limits on urban, rural and highways and the other scenario (S2) considers the lowest average speed under those driving conditions.

- Mileage Share (MS): Mileage share is another very important factor in emissions calculation as the operating speed, road characteristics, traffic densities and thereby the exhausted emissions are different on regional roads, local roads, national roads etc. In COPERT, mileage share information is required for urban, rural and highways. The base mileage shares were taken as $30 \%, 50 \%$ and $20 \%$ for urban, rural, and highway respectively. Three scenarios have been designed (see table 3), to capture the variability, denoted as MS1, MS2, MS3. The 
scenarios are designed such that the sensitivity of emission to each driving mode can be studied by comparing the results which are presented separately for each driving mode.

- Trip Length (TL): It is required to provide the average trip length $(\mathrm{km})$ in COPERT. A single average trip length value is considered for a country average trip length. This is likely to vary and is important to see the impact of trip length on emission levels. This will also help to identify those trips causing more emissions and thereby finding alternatives to replace those trips to reduce emission levels. The trip length for the base case was taken as $15.1 \mathrm{~km}(\mathrm{CSO}$, 2014). Six scenarios (TL1, TL2, TL3, TL4, TL5, and TL6), as shown in table 3, were considered by increasing and reducing the average base trip length by $20 \%$.

\subsubsection{Factor interaction}

In this case, the effects of multi-factor variation on emission levels have been studied. Emissions were calculated by varying two or more factors simultaneously. The designed scenarios are described in the following subsections.

- Temperature-Relative Humidity: This scenario studies the impact of variability of the weather parameters, i.e. temperature and RH that are considered in COPERT 5, on emission levels. The emission variations were studied for these two sets of RH (base and RH1) values against four temperature scenarios described in section 3.3.1. (i.e. base, T1, T2, and T3). Therefore total $2 \times 4$ emission estimates were obtained.

- Urban Speed-Trip Length: It was found that emission levels are significantly sensitive to urban speed and trip length. Therefore, average urban speed and trip length were varied simultaneously to understand their interaction. In this scenario, a range of possible urban speeds and trip lengths were studied in terms of their impact on vehicular emissions. Based on the national travel survey data, a range of trip lengths varying from 5-19 km. and an urban speed range of $20-45 \mathrm{kmph}$ was examined.

- Urban Speed-Trip Length-Urban Driving Share: The results show that rural and highway emissions increase or decrease by the same percentage if the rural and highway driving shares 
are changed by certain percentages. However, it was observed that urban emission share is more sensitive to the urban mileage shares. Therefore, the speed and trip length combinations tested in the previous scenario were run for three additional driving shares, $20 \%, 40 \%$, and $50 \%$.

\subsection{Uncertainty analysis:}

Uncertainty associated with COPERT 5 outputs were modelled by identifying characteristics of probability distributions of the pollutant emissions. The emissions estimated from all the scenarios were plotted as a histogram and fitted to the most suitable probability distribution function. Therefore, the sources of uncertainties related to input parameters were taken into account. The goodness of fit was tested using Kolmogorov-Smirnov (K-S) test at 5\% significance level.

\section{Results and discussion}

In this section, the findings of this study are presented and observations from the results have been discussed.

\subsection{Current Inventory for Ireland and GDA}

The emissions for the year 2015 in Ireland and GDA are presented in this section. Table 4 shows the passenger car emission inventories of $\mathrm{CO}, \mathrm{CO}_{2}, \mathrm{NOx}, \mathrm{PM}_{2.5}, \mathrm{PM}_{10}$, VOC, $\mathrm{NMVOC}$ and $\mathrm{N}_{2} \mathrm{O}$ for GDA and Ireland as calculated using COPERT 5.

\section{Table 4}

Passenger car emissions inventory (2015) for GDA and Ireland.

\begin{tabular}{|c|c|c|c|c|c|c|c|c|}
\hline & \multicolumn{8}{|c|}{ Emissions (tonnes) } \\
\hline & $\mathrm{CO}$ & $\mathrm{CO}_{2}$ & $\mathrm{NO}_{\mathrm{X}}$ & $\mathrm{PM}_{2.5}$ & PM10 & VOC & NMVOC & $\mathrm{N}_{2} \mathrm{O}$ \\
\hline Ireland & 35,558 & $6,095,743$ & 13,765 & 772.46 & 1038.73 & 3057.99 & 2717.38 & 182.35 \\
\hline GDA & 22,380 & $2,925,957$ & 6934 & 339.34 & 410.61 & 1817.36 & 1612.49 & 94.04 \\
\hline
\end{tabular}

$\mathrm{CO}_{2}$ emissions in Ireland from private car alone in 2015 was $6.095 \mathrm{Mt}$. GDA shares $62.94 \%, 48.00 \%$, $50.37 \%, 43.93 \%, 39.53 \%, 59.43 \%, 59.34 \%, 51.57 \%$ of overall Ireland's $\mathrm{CO}, \mathrm{CO}_{2}, \mathrm{NO}_{\mathrm{X}}, \mathrm{PM}_{2.5}, \mathrm{PM}_{10}$, 
VOC, NMVOC and $\mathrm{N}_{2} \mathrm{O}$ emissions respectively. This indicates a higher impact of pollution on the GDA population than the rest of the country.

\subsection{Effect of input parameters on emission}

\subsubsection{One Factor at a time \\ - Temperature Scenario}

Temperature is an important parameter in emission levels as it affects the cold start and evaporative emission factors. Evaporative emissions are non-exhaust hydrocarbon losses from the fuel system of vehicle. The results obtained from the temperature scenario are presented in Fig. 5. The results show that when extreme temperatures are considered, the difference in emissions levels is not significant. The maximum difference was found for cold start PM emissions which are $0.8 \%$ though the difference in total emissions is $0.1 \%$. The reason behind this can be the increase in cold start emission due to lower temperature is neutralised by the lower emissions when the maximum average temperature is higher than the base. To capture the emissions behaviour with lower temperature and higher temperature, T2 and T3 have been designed. T2 and T3 represent more realistic situations as the mode of the daily temperature gaps between lowest and highest temperatures are taken into consideration. From the emission values in Fig. 5, it is observed that levels for cold and evaporative emissions increase (especially for $\mathrm{CO}, \mathrm{PM}$, and VOC) when the average monthly minimum and maximum temperatures are lower than that in the base scenario. The non-exhaust emissions which are the particulate (PM) emissions due to wear of brakes, tires, roads and re-suspended road dust, are also presented in Fig. 5. Non-exhaust emissions in the temperature scenarios do not show any notable variation.

The results obtained for T3 (Fig. 5), support the observation from T2 as the emission levels decrease when both the minimum and maximum monthly average temperature were taken to be higher than the base case temperatures. The reduction in cold start emissions for $\mathrm{CO}, \mathrm{NOx}, \mathrm{PM}_{2.5}, \mathrm{VOC}$, and NMVOC were $6.6 \%, 8.2 \%, 14 \%, 6.2 \%$ and $6.8 \%$ respectively from the base scenario. 

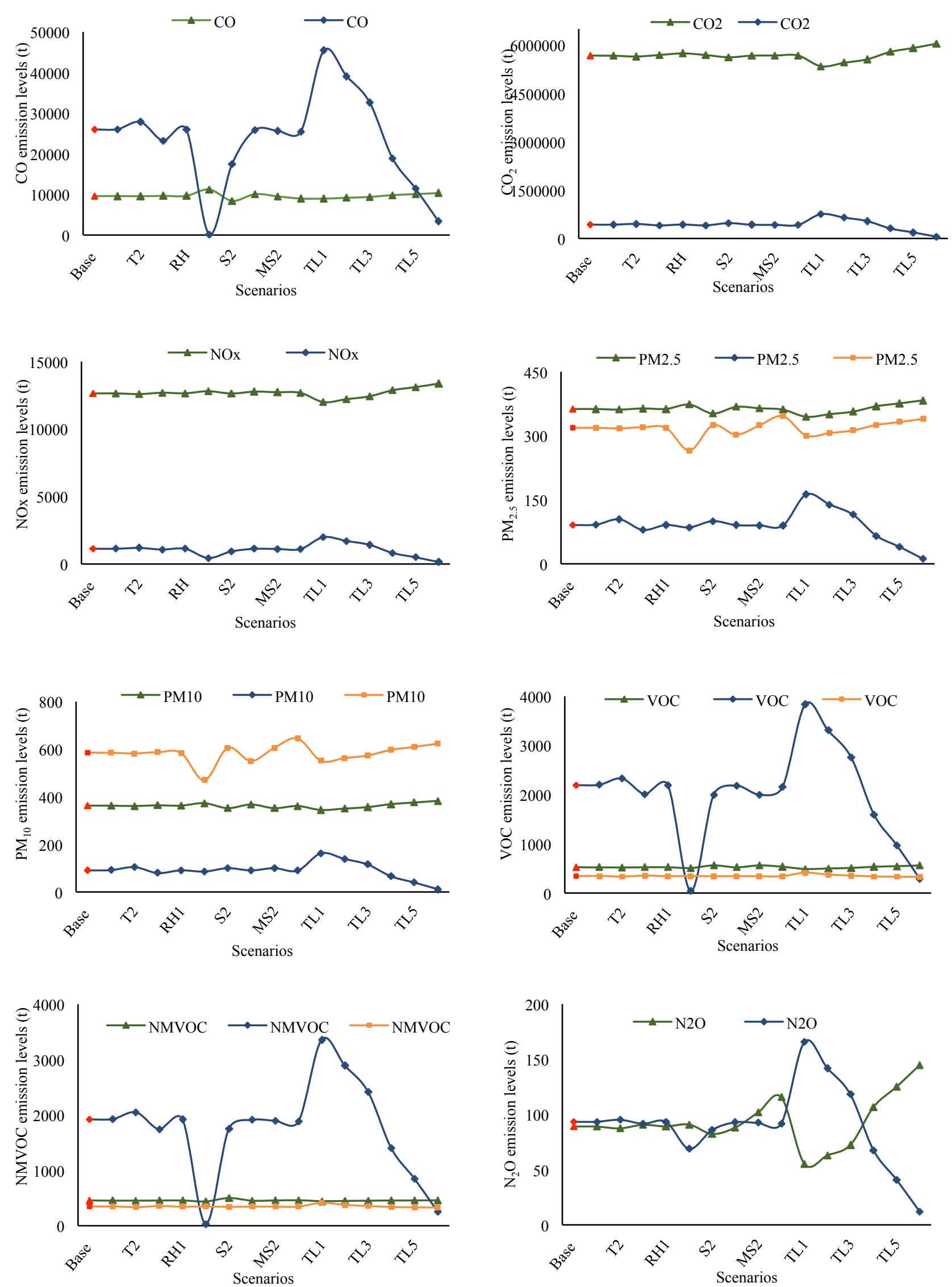
Fig. 5. Annual hot, cold, non-exhaust and evaporative emissions of $\mathrm{CO}, \mathrm{CO}_{2}, \mathrm{NOx}, \mathrm{PM}_{2.5}, \mathrm{PM}_{10}$, VOC, NMVOC, $\mathrm{N}_{2} \mathrm{O}$ from all the scenarios.

There is no significant difference in emission levels when extreme monthly temperatures were taken which is because the increase in cold start emission levels due to lower temperature was balanced by the reduction in cold-start emissions due to higher maximum temperature compared to the base. However, when the minimum monthly temperatures were considered lower (T2) than the base temperature the cold start and evaporative emissions increase. Whereas, when the monthly average maximum temperatures were higher (T3) than the base, cold start and evaporative emission levels were lower. However, there were no significant differences in hot exhaust emissions in any of the scenarios, thus, it can be said that temperature mainly affects cold-start emission levels.

\section{- Relative Humidity Scenario}

The results show that there is no significant change in emission estimates when modes of the relative humidity values were taken instead of average values for the same monthly temperature values. Relative humidity is correlated to temperature; therefore, the impact of humidity can be better understood in the next section where the humidity and temperature are varied simultaneously.

\section{- $\quad$ Speed Scenario}

It is observed that in S1 (Fig. 5) i.e. when the speed limits are taken as the average operating speeds, there is a significant reduction in emission levels in VOC (70.7\%) followed by NMVOC (69.9\%), CO (67.9\%) and $\mathrm{PM}_{10}(10.6 \%)$. Whereas in $\mathrm{S} 2$ (Fig. 5), the differences in emission levels are not high except for $\mathrm{CO}(27.1 \%)$. When the average operating speed values were taken equal to the speed limits (S1) emission levels were lower which is expected as the fuel consumption is lesser when the speed is higher. Lower average speed resulted in an increase in emissions from diesel cars but a decrease in petrol powered cars, thereby, decrease in overall emission levels as there are more petrol vehicles in the overall fleet. This can be linked to the presence of more number of diesel vehicles and less number of petrol vehicles with larger engine size in the fleet. Based on this observation, it may also be said that larger engine sized vehicles are more affected by average operating speeds than vehicles with a 
smaller engine. It was identified that $\mathrm{CO}, \mathrm{NOx}, \mathrm{PM}_{2.5}, \mathrm{PM}_{10}$, VOC, NMVOC, $\mathrm{N}_{2} \mathrm{O}$ emissions could be saved significantly if a higher average speed equal to the speed limit could be maintained.

\section{- $\quad$ Mileage Share Scenario}

Three mileage share scenarios have been designed to create the emissions inventory and to observe the effect of each type of driving condition on emission levels. In Table 5, separate emission levels resulted from urban, rural and highway driving have been showed with the percentage differences with respect to the base scenario.

\section{Table 5}

Emission levels for mileage share scenarios.

\begin{tabular}{|c|c|c|c|c|c|c|c|c|c|}
\hline \multirow[t]{2}{*}{ Scenario } & \multirow{2}{*}{$\begin{array}{l}\text { Driving mode } \\
\text { share }\end{array}$} & \multicolumn{8}{|c|}{ Pollutants } \\
\hline & & $\mathrm{CO}$ & $\mathrm{CO}_{2}$ & NOx & $\mathrm{PM}_{2.5}$ & $\mathrm{PM}_{10}$ & VOC & NMVOC & $\mathrm{N}_{2} \mathrm{O}$ \\
\hline \multirow[t]{3}{*}{ Base } & Urban $(\mathrm{t})$ & 28587 & $2.3 * 10^{6}$ & 5257 & 331 & 443 & 2649 & 2367 & 112 \\
\hline & Rural (t) & 4272 & $2.7 * 10^{6}$ & 5826 & 328 & 463 & 274 & 235 & 51 \\
\hline & Highway (t) & 2699 & $1.1 * 10^{6}$ & 2682 & 114 & 133 & 135 & 116 & 19 \\
\hline \multirow[t]{3}{*}{ MS1 } & $\%$ change (Urban) & 0 & 0 & 0 & 0 & 0 & 0 & 0 & 0 \\
\hline & $\%$ change (Rural) & -20 & -20 & -20 & -20 & -20 & -18 & -17 & -20 \\
\hline & $\begin{array}{l}\% \text { change } \\
\text { (Highway) }\end{array}$ & 49 & 49 & 49 & 49 & 49 & 37 & 35 & 49 \\
\hline \multirow[t]{3}{*}{ MS2 } & $\%$ change (Urban) & 2 & 26 & 25 & 23 & 25 & 1 & 1 & 20 \\
\hline & $\%$ change (Rural) & -21 & -21 & -21 & -21 & -21 & -18 & -18 & -21 \\
\hline & $\begin{array}{l}\% \text { change } \\
\text { (Highway) }\end{array}$ & -1 & -1 & -1 & -1 & -1 & -1 & -31 & -1 \\
\hline \multirow[t]{3}{*}{ MS3 } & $\%$ change (Urban) & 4 & 51 & 50 & 46 & 50 & 3 & 2 & 41 \\
\hline & \% change (Rural) & -22 & -21 & -21 & -21 & -21 & -19 & -18 & -21 \\
\hline & $\begin{array}{l}\% \text { change } \\
\text { (Highway) }\end{array}$ & -51 & -51 & -51 & -51 & -51 & -38 & -36 & -51 \\
\hline
\end{tabular}

The results indicate that $\mathrm{CO}_{2}, \mathrm{NO}_{\mathrm{X}}$, and $\mathrm{PM}$ are more sensitive to urban driving share. It is observed that with $10 \%$ increase in urban driving share $\mathrm{CO}_{2}$ emissions increase by $26 \%$ and $\mathrm{NO}_{\mathrm{X}}$ and $\mathrm{PM}_{2.5}$ increase by $25 \%$ and $23 \%$ respectively, whereas, with $10 \%$ reduction in rural share emissions reductions are around $20 \%$ for all the major air pollutants. Whereas $10 \%$ decrease in highway driving share results in about $50 \%$ lower emissions for $\mathrm{CO}, \mathrm{CO}_{2}, \mathrm{PM}, \mathrm{NO}_{\mathrm{X}}$, and $\mathrm{N}_{2} \mathrm{O}$ and $38 \%$ for $\mathrm{VOC}$.

\section{- $\quad$ Trip length Scenario}

In this paper, six trip lengths, of which three were taken by reducing the base trip lengths by $20 \%, 40 \%$ and $60 \%$ and other three by increasing the trip lengths by the same percentages were considered. The trip lengths examined were of $6.0 \mathrm{~km}, 9.1 \mathrm{~km}, 12.1 \mathrm{~km}, 18.1 \mathrm{~km}$ and $24.2 \mathrm{~km}$ length. Table 6 presents 
total emissions from the base case with the average trip length of $15.1 \mathrm{~km}$ and the percentage increase and decrease with the change in trip length. Fig. 5 shows cold start, hot exhaust, evaporative and nonexhaust emissions separately for all trip length scenarios.

\section{Table 6}

Base case emission levels and percentage difference in emission levels for trip length scenarios.

\begin{tabular}{|c|c|c|c|c|c|c|c|}
\hline \multirow{3}{*}{ Pollutant } & \multicolumn{7}{|c|}{ Trip length(km) } \\
\hline & 15.1 & 6.0 & 9.1 & 12.1 & 18.1 & 21.1 & 24.2 \\
\hline & $\begin{array}{c}\text { Emission level } \\
(\mathrm{t})\end{array}$ & \multicolumn{6}{|c|}{ Percentage difference from the base $(\%)$} \\
\hline $\mathrm{CO}$ & 35,558 & 53 & 36 & 18 & -19 & -39 & -61 \\
\hline $\mathrm{CO}_{2}$ & $6,095,743$ & 0 & 0 & 0 & 0 & 0 & 0 \\
\hline $\mathrm{NOx}$ & 13,765 & 2 & 1 & 0.6 & -0.6 & -1 & -2 \\
\hline $\mathrm{PM}_{2.5}$ & 772 & 5 & 3 & 2 & -2 & -3 & -5 \\
\hline $\mathrm{PM}_{10}$ & 1039 & 2 & 1 & 0.6 & -0.7 & -1 & -2 \\
\hline VOC & 3058 & 55 & 37 & 19 & -19 & -40 & -62 \\
\hline NMVOC & 2717 & 55 & 37 & 19 & -19 & -40 & -62 \\
\hline $\mathrm{N}_{2} \mathrm{O}$ & 182 & 21 & 12 & 4 & -4 & -9 & -14 \\
\hline
\end{tabular}

It can be observed from the results that the emissions for the shorter trips are significantly higher, especially for $\mathrm{CO}$, VOC, and NMVOC, and with the increase in average trip length emission levels decreases. It was found that for lower average trip lengths emission levels for CO, VOC, NMVOC increase by $52-55 \%$. For the average trip lengths varying from $18.1-24.2 \mathrm{~km}$, the possible emissions savings range between $19-62 \%$ for CO, VOC, and NMVOC. This observation is in line with the findings of other researchers (Vanhulsel et al., 2014; Fameli and Assimakopoulos, 2015). There is no significant difference in $\mathrm{CO}_{2}$ emissions was found, as it is mainly influenced by other factors such as speed, fuel type, engine size etc. The fact that emission levels increase with the decrease in average trip length for the same annual mileage indicates the possibility of significant emissions savings by replacing the shorter trips with walking or cycling.

Total emission levels of all the pollutants from all the scenarios have been presented in Fig. 6 by the box-whisker plot to see the range of variations. The horizontal lines present the minimum and maximum values and the red line inside the box shows the median. The black horizontal lines above 

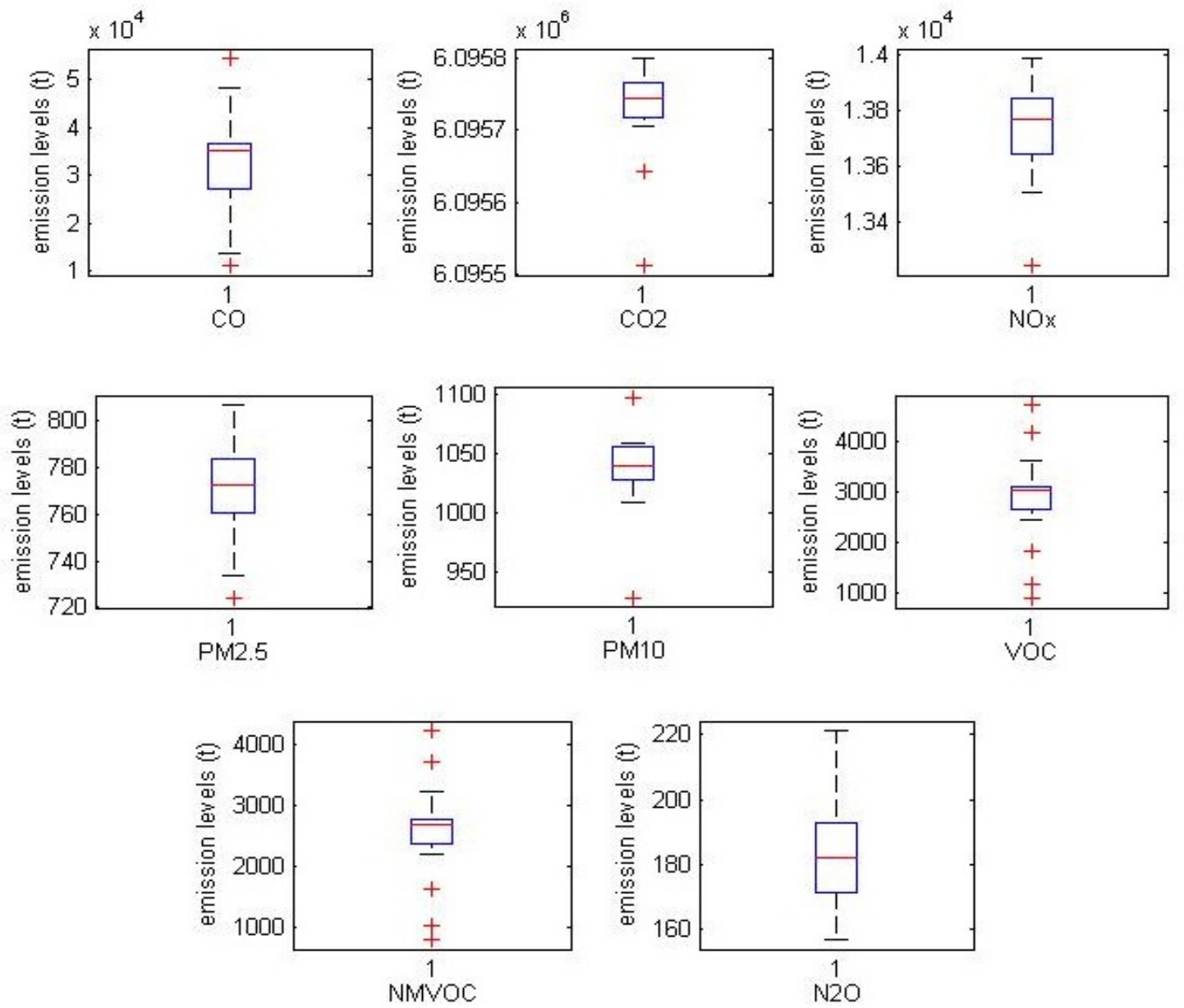

Fig. 6. Range of variability of emission levels of $\mathrm{CO}, \mathrm{CO}_{2}, \mathrm{NOx}, \mathrm{PM}_{2.5}, \mathrm{PM}_{10}, \mathrm{VOC}, \mathrm{NMVOC}$ and $\mathrm{N}_{2} \mathrm{O}$.

and below the box present the minimum and maximum values. The figures show that there are significant variations in emission levels due to possible variation in input parameters.

\subsubsection{Factor Interaction:}

- Temperature-Relative Humidity:

This section presents the emission variations against temperature and RH scenarios as shown in Fig. 7. For $\mathrm{CO}_{2}, \mathrm{NOx}, \mathrm{PM}_{2.5}, \mathrm{PM}_{10}$, and $\mathrm{N}_{2} \mathrm{O}$, emissions are affected by $\mathrm{T} 2$. Therefore, it is observed that when both the lower and upper limit of average monthly temperature is lower than average, emission estimates of those pollutants are sensitive to relative humidity. However, for T1 or T3, which considers relatively higher temperature ranges, the variation in emission levels are not significant. Also, there is no significant difference observed for CO, VOC, and NMVOC in any of the scenarios 
compared to the base case. This indicates that these pollutants are not sensitive to relative humidity in the temperature ranges explored in this study. Although the emissions of some pollutants are sensitive to temperature and relative humidity, it depends largely on their interaction. More temperature and relative humidity scenarios can be examined for other countries which experience different weather conditions than Ireland.

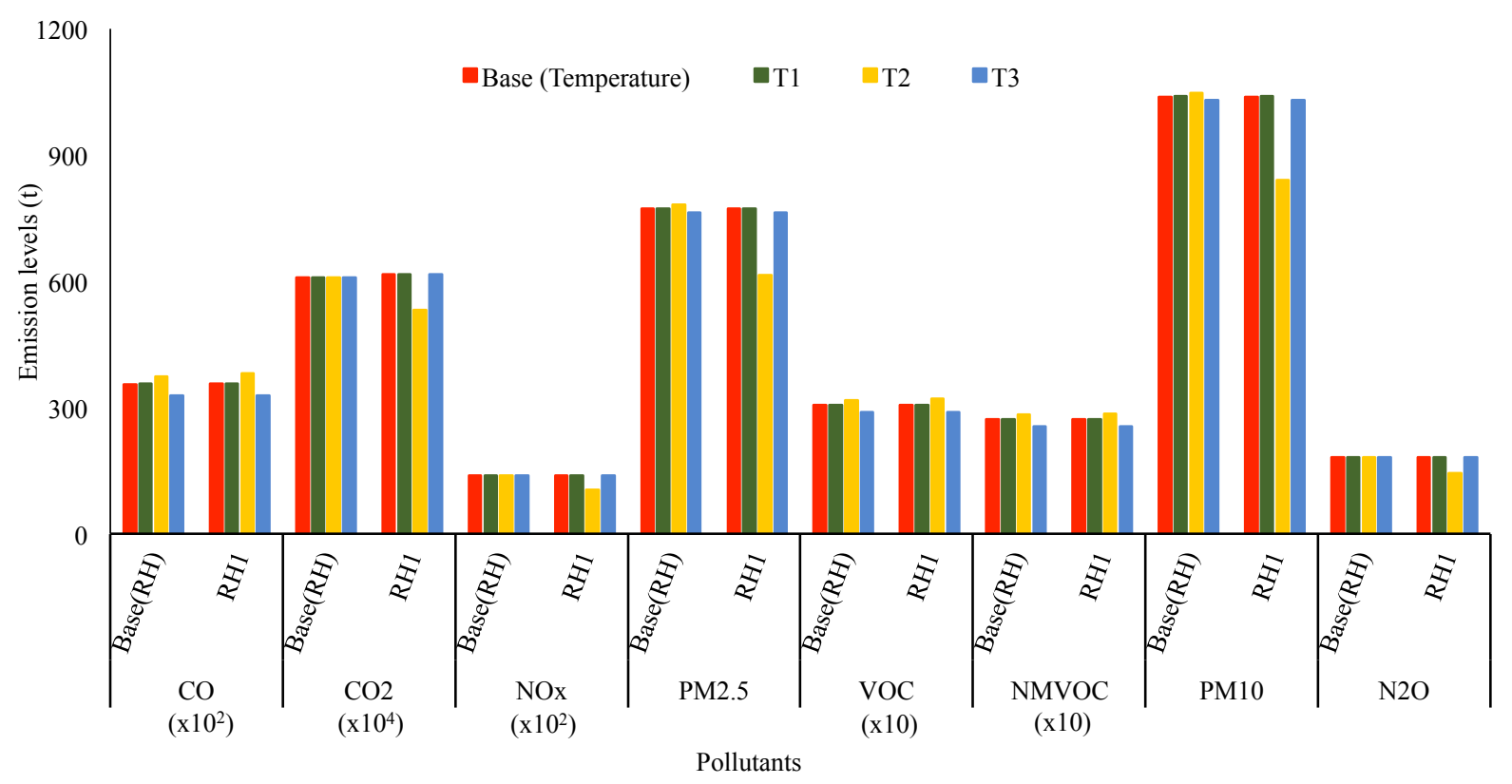

Fig. 7. Annual emission levels against Temperature and Relative humidity.

- Urban speed-Trip Length:

Fig. 8 illustrates the 3D surface plots of $\mathrm{CO}, \mathrm{CO}_{2}, \mathrm{NOx}, \mathrm{PM}_{2.5}, \mathrm{PM}_{10}, \mathrm{VOC}, \mathrm{NMVOC}$ and $\mathrm{N}_{2} \mathrm{O}$ emissions against the average urban speed and trip length variations. All the pollutants follow a similar pattern as for individual parameter variations except NOx. For NOx, for lower speed in case of 20 and 25, emissions increase with increase with average trip length but in case of speed 30 or higher, NOx emission levels increase with an increase in average trip length. For $\mathrm{CO}_{2}$, the effect of speed is least with respect to the speed variation. For CO, VOC, and NMVOC, emission levels decrease with increase in speed till $30 \mathrm{kmph}$ and then start to increase. But as observed in $\mathrm{S} 1$, emissions start to decrease after that due to lower cold start emissions. 

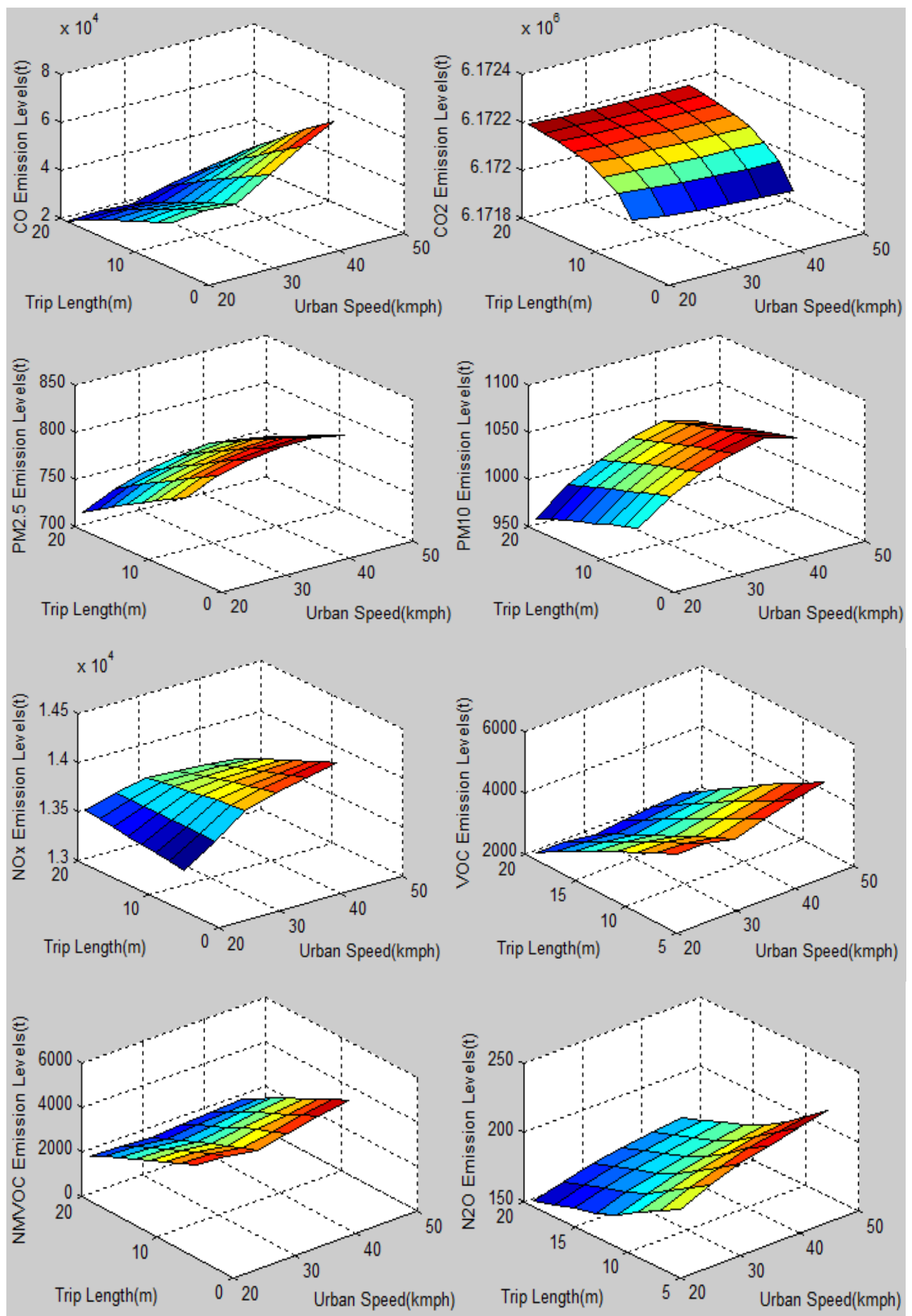

Fig. 8. 3D surface plots showing variations of annual emissions vs Trip Length and Urban Speed.

\subsection{Uncertainty Analysis:}


The probability density functions (PDF) of COPERT 5 passenger car emissions outputs are presented in this section. In addition to the scenario results presented in the previous sections, emission levels at other urban shares $(20 \%, 40 \%$, and $50 \%)$ were run for the same trip length and urban share combinations as shown in Fig. 8. PDFs and the statistical parameters explaining the nature of the distributions are listed in Table 7. The coefficient of variation values presented in Table 7 indicate that $\mathrm{CO}_{2}, \mathrm{PM}_{2.5}, \mathrm{NOx}$, and $\mathrm{PM}_{10}$ have a lower level of uncertainty in estimation with respect to input parameter variations in COPERT 5. However, $\mathrm{CO}$, VOC, NMVOC, and $\mathrm{N}_{2} \mathrm{O}$ have a higher level of uncertainty.

\section{Table 7}

Statistical analysis results for each pollutant.

\begin{tabular}{lccccccc}
\hline Pollutant & $\begin{array}{c}\text { Sample } \\
\text { Size }\end{array}$ & Mean & $\begin{array}{c}\text { Standard } \\
\text { deviation }\end{array}$ & $\begin{array}{c}\text { Coefficient } \\
\text { of variation }\end{array}$ & Skewness & Kurtosis & PDF \\
\hline $\mathrm{CO}$ & 187 & 34,205 & 9450 & 27.63 & 0.52 & 0.16 & Lognormal(3P) \\
$\mathrm{CO}_{2}$ & 171 & $6,161,406$ & 65788 & 1.07 & -1.06 & 0.14 & Lognormal \\
$\mathrm{NOx}$ & 186 & 13,747 & 300 & 2.18 & -0.35 & -0.29 & Lognormal \\
$\mathrm{PM}_{2.5}$ & 187 & 771 & 27 & 3.44 & -0.20 & -0.57 & Lognormal \\
$\mathrm{VOC}$ & 67 & 3253 & 893 & 27.44 & -0.34 & 0.08 & Gamma \\
$\mathrm{NMVOC}$ & 67 & 2951 & 783 & 26.52 & -0.17 & -0.02 & Log-Logistic \\
$\mathrm{PM}_{10}$ & 67 & 1023 & 36 & 3.48 & -0.52 & 0.61 & Weibull \\
$\mathrm{N}_{2} \mathrm{O}$ & 67 & 186 & 19 & 10.19 & 0.35 & -0.36 & Lognormal \\
\hline
\end{tabular}

It has been statistically tested that the best-fitted PDFs of $\mathrm{CO}, \mathrm{CO}_{2}, \mathrm{NOx}, \mathrm{PM}_{2.5}$, and $\mathrm{N}_{2} \mathrm{O}$ are lognormal distributions, VOC is gamma, NMVOC is log-logistic and $\mathrm{PM}_{10}$ is weibull at $5 \%$ significance level. Fig. 9 illustrates the frequency histograms and PDFs for $\mathrm{CO}, \mathrm{PM}_{2.5}, \mathrm{VOC}, \mathrm{N}_{2} \mathrm{O}$, $\mathrm{PM}_{10}$, and NMVOC.
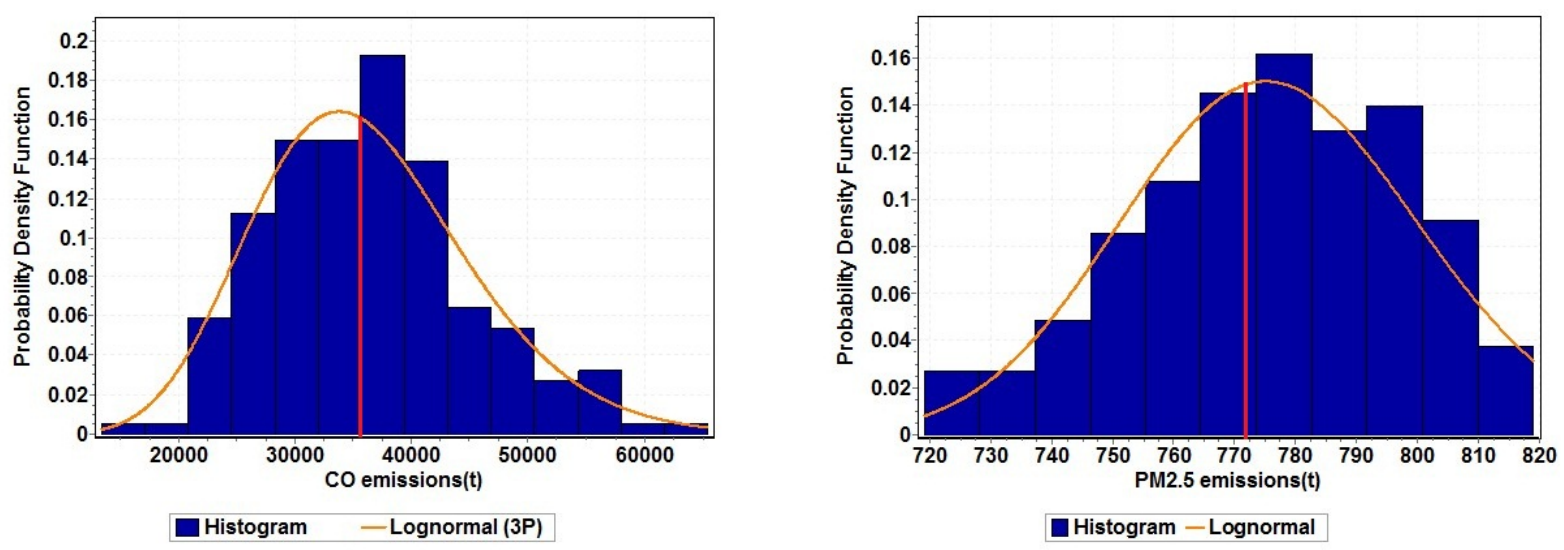

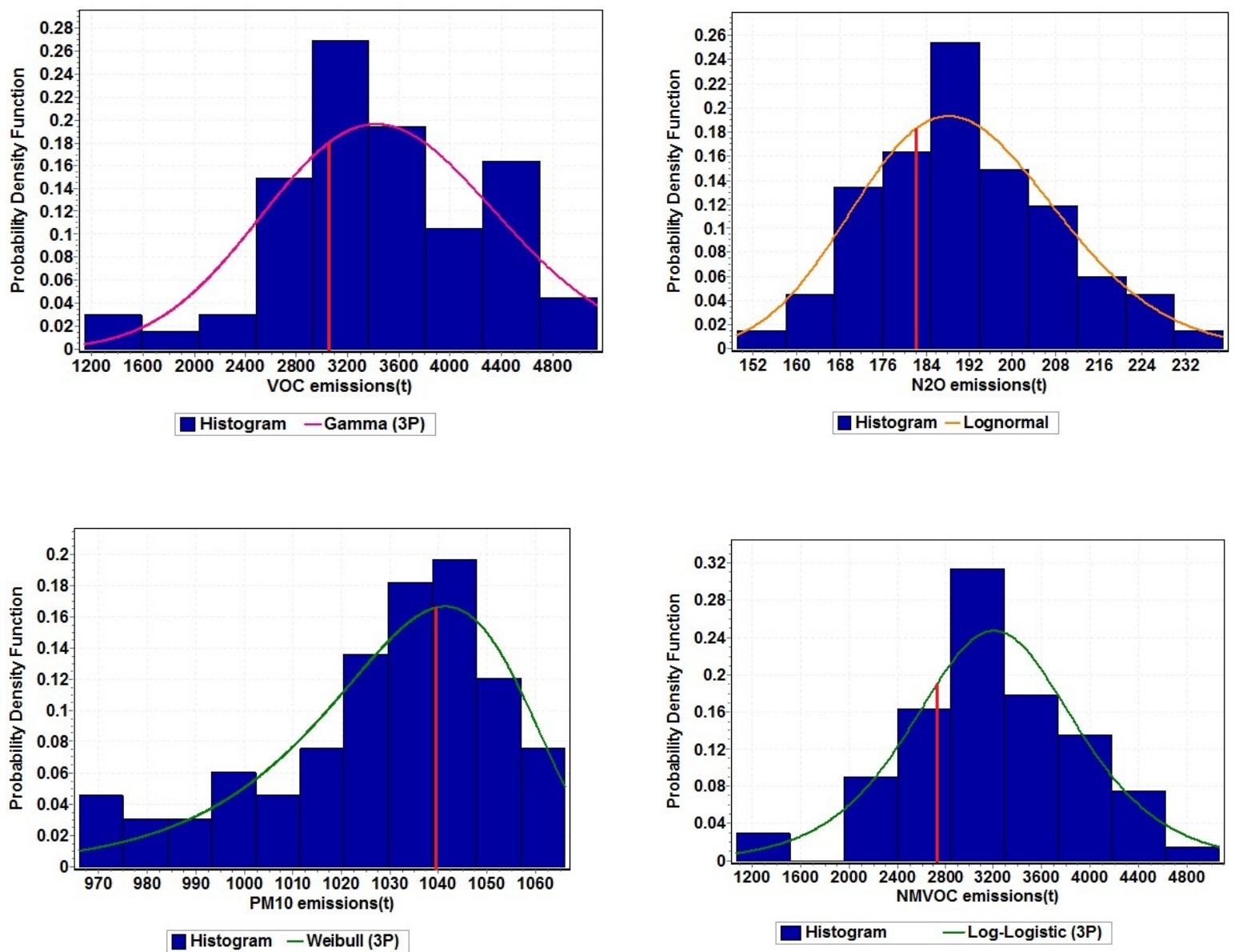

Fig. 9. Histograms and PDFs of annual passenger car emission levels. (Red line indicates the base case emission levels)

\section{- Cost implication:}

Greenhouse and non-greenhouse gases directly or indirectly cause damage to human health, crops, materials, plant and animal diversity. These damages caused by road transport emissions can be monetised using emission values ( $€$ per tonne) (Table 8$)$ reported by DTTaS (2016) and in the handbook on external costs of transport (Ricardo-AEA, 2014). Based on the emission results from all the model runs, the damage costs in the base case and possible minimum and maximum have been reported in this section (Table 8). This gives information about the possible range of variation in damage costs depending on potential variations in emission estimates.

\section{Table 8}


Emissions and emissions values of pollutants in base, possible minimum and possible maximum cases.

\begin{tabular}{|c|c|c|c|c|c|c|c|}
\hline \multirow[t]{2}{*}{ Pollutants } & \multirow{2}{*}{$\begin{array}{l}\text { Emissions } \\
\text { values } \\
(€ / t) \\
\end{array}$} & \multicolumn{2}{|c|}{ Base } & \multicolumn{2}{|c|}{ Minimum } & \multicolumn{2}{|c|}{ Maximum } \\
\hline & & $\begin{array}{l}\text { Emissions } \\
(\mathrm{t})\end{array}$ & $\begin{array}{c}\text { Damage } \\
\text { costs (mil€) }\end{array}$ & $\begin{array}{l}\text { Emissions } \\
(\mathrm{t})\end{array}$ & $\begin{array}{c}\text { Damage } \\
\text { costs (mil€) }\end{array}$ & $\begin{array}{l}\text { Emissions } \\
(\mathrm{t})\end{array}$ & $\begin{array}{l}\text { Damage } \\
\text { costs }(€)\end{array}$ \\
\hline $\mathrm{CO}_{2}$ & 13.22 & $6,095,743$ & 80.59 & $6,095,514$ & 80.58 & $6,172,219$ & 81.60 \\
\hline $\mathrm{PM}_{10}$ & 19143 & 1039 & 19.88 & 841 & 16.09 & 1060 & 20.29 \\
\hline $\mathrm{NOx}$ & 5851 & 13,765 & 80.54 & 10,507 & 61.48 & 14,140 & 82.73 \\
\hline $\mathrm{VOC}$ & 1438 & 3058 & 4.40 & 896 & 1.29 & 5124 & 7.37 \\
\hline NMVOC & 1398 & 2717 & 3.80 & 818 & 1.14 & 4573 & 6.39 \\
\hline $\begin{array}{l}\mathrm{PM}_{2.5} \\
\text { (urban) }\end{array}$ & 200239 & 331 & 66.26 & 267 & 53.41 & 536 & 107.24 \\
\hline $\begin{array}{l}\mathrm{PM}_{2.5} \\
\text { (suburban) }\end{array}$ & 48779 & 114 & 5.54 & 88 & 4.28 & 105 & 5.12 \\
\hline $\begin{array}{l}\mathrm{PM}_{2.5} \\
\text { (rural) }\end{array}$ & 16985 & 328 & 5.57 & 260 & 4.41 & 182 & 3.08 \\
\hline $\begin{array}{ll}\begin{array}{l}\text { Total } \\
(m i l €)\end{array} & \text { da } \\
\end{array}$ & lage cost & \multicolumn{2}{|c|}{266.58} & \multicolumn{2}{|c|}{222.68} & \multicolumn{2}{|c|}{313.83} \\
\hline
\end{tabular}

As can be observed from Table 8, the damage cost of $\mathrm{PM}_{2.5}$ in urban areas is very high compared to damage costs in suburban and rural areas. Total cost of damage due to pollution from PC fleet in Ireland was found to be $€ 266.58$ million in the base case with highest cost associated with $\mathrm{CO}_{2}$, followed by NOx and $\mathrm{PM}_{2.5}$. However, the costs calculated for possible minimum and maximum scenarios show that there is possibility of overestimation by $€ 43.9$ million or underestimation by $€ 47.25$ million in the base scenario. It is also to be noted that even though the per tonne damage cost of NOx is lesser than $\mathrm{PM}_{2.5}$, total cost is greater for $\mathrm{NOx}$ than $\mathrm{PM}_{2.5}$. This indicates higher level of NOx pollution from PC fleet.

\section{Conclusion}

Considering the major applications of the national emissions inventory, it is important to calculate emission levels as accurately as possible. This paper explores the uncertainties of $\mathrm{CO}, \mathrm{CO}_{2}, \mathrm{NOx}$, $\mathrm{PM}_{2.5}, \mathrm{PM}_{10}, \mathrm{VOC}, \mathrm{NMVOC}$ and $\mathrm{N}_{2} \mathrm{O}$ emissions from passenger cars due to input parameter variations in COPERT 5. Effect of the factors whose values are not accurately available or not always measured or averages are considered in preparing emissions inventory for the whole country, have been identified and the sensitivity of emission levels to those input parameters have been explored in this study. This provides useful information to the users of COPERT 5 in terms of the degree of precision that each of the input parameters requires. Hot exhaust, cold start, evaporative and nonexhaust emissions are presented for all the major air pollutants to have a better understanding of their 
emissions behaviour. Results show that emission levels are more sensitive to average operating speed and average trip length which are measured from sample sets. However, no significant variation in overall emission levels was observed with rural and highway mileage share variation which are not measured. The results revealed that overall emission levels of $\mathrm{CO}, \mathrm{VOC}, \mathrm{NMVOC}, \mathrm{N}_{2} \mathrm{O}$ are more sensitive than $\mathrm{CO}_{2}, \mathrm{NOx}, \mathrm{PM}$ to the parameters evaluated in this study. Uncertainty associated with $\mathrm{CO}_{2}$ is lesser $(-0.004$ to $1.3 \%)$ with respect to those input parameter variation ranges. However, uncertainty in $\mathrm{CO}$, VOC, NMVOC and $\mathrm{N}_{2} \mathrm{O}$ estimates depends more upon average trip length, urban driving share and urban driving speed. The annual emissions levels presented in this study indicate that, in reality, the emission levels might be much lower (up to $58 \%$ for $\mathrm{CO}$, VOC, and NMVOC) or much higher (up to $79 \%$ for $\mathrm{CO}$, VOC, and NMVOC) depending on the level of variation of the input parameters. Uncertainty in PM and NOx emission levels may deviate from the reported estimates by 24 to $3 \%$. For $\mathrm{N}_{2} \mathrm{O}$, the under- and over-estimation may lie between 21 and $31 \%$ respectively. Depending on the extent of variations in input parameters, the damage costs of air pollution caused by passenger cars in Ireland can be lower by $16 \%$ or higher by $18 \%$ than the base case. The accurate consideration of the input parameters may result in an emission level significantly higher or lower than the current consideration leading to a better planning, modelling and policy making. Therefore, it is always recommended that rather than reporting a single value of emission, a range of uncertainty for emission values should accompany the emission estimates to allow more credibility and transparency of the estimates.

Acknowledgment: The authors would like to thank the Environmental Protection Agency, Ireland for funding this research under the Greening Transport project (Grant no. CEEPA 2014-CCRP-MS.18).

\section{Reference:}

Achour, H., Olabi, A., G., Carton, J.G., 2011. Estimating Vehicle Emissions from Road Transport, Case study: Dublin City. Appl. Energy, 88, 1957-1964. DOI: 10.1016/j.apenergy.2010.12.032

Alam, M.S., Duffy, P., Hyde, B., McNabola, A., 2015. Estimation and back extrapolation of $\mathrm{CO}_{2}$ emissions from the road transport sector: emissions in Ireland, 1990 to 2013. Air Pollut. XXII, 198, 63-75. DOI: 10.2495/AIR150061 
Andrias, A., Samaras, Z., Zachariadis, Th., Zierock, K.H., 1993. TNO/EURASAP workshop on the reliability of VOC emission databases, Delft.

Asia Center for Air Pollution Research (ACAP), 2010. What is an Emission Inventory. Japan Environmental Sanitation center. http://www.acap.asia/publication/pdf/emissioneng.pdf

Berkowicz, R., Winther, M., Ketzel, M., 2006. Traffic pollution modelling and emission data. Environ. Modell. \& Softw., 21, 454-460. DOI:10.1016/j.envsoft.2004.06.013.

Borge, R., Miguel, I.D., Paz, D.D.L., Lumbreras, J., Pérez, J., Rodríguez, E., 2012. Comparison of road traffic emission models in Madrid (Spain). Atmos. Environ. , 62, 461-471.

Borrego, C., Monteiro, A., Ferreira, J., Miranda, A.I., Costa, A.M., Carvalho, A.C., Lopes, M., 2008. Procedures for estimation of modelling uncertainty in air quality assessment. Environ. Int., 34, 613620. DOI:10.1016/j.envint.2007.12.005

Brady, J., O'Mahony, M., 2011. Travel to work in Dublin. The potential impacts of electric vehicles on climate change and urban air quality. Transport. Res. Part D, 16, pp. 188-193. DOI: $10.1016 /$ j.trd.2010.09.006

Caulfield, B., 2009. Estimating the environmental benefits of ride-sharing: a case study of Dublin. Transport. Res. Part D , 14, $527-531$.

Central Statistics Office (CSO), 2011. Population of each Province, County and City. http://www.cso.ie/en/statistics/population/populationofeachprovincecountyandcity2011/ (accessed 19 April 2017).

Central Statistics Office (CSO), 2012. Profile 1-Town and County. http://www.cso.ie/en/media/csoie/census/documents/census2011vollandprofile1/Profile1 Town and _Country_Entire_doc.pdf

Central Statistics Office (CSO), 2014. National Travel Survey. http://www.cso.ie/en/releasesandpublications/ep/p-nts/nationaltravelsurvey2014/keyfindings/ (accessed 27 February 2017).

Central Statistics Office (CSO), 2014. Average kilometres travelled by road traffic. http://www.cso.ie/multiquicktables/quickTables.aspx?id=tha10_3 (accessed 27 February 2017).

Central Statistics Office (CSO), 2016. Road vehicle population. http://www.cso.ie/multiquicktables/quickTables.aspx?id=tha10_1 (accessed 27 February 2017).

Central Statistics Office (CSO), 2016. Census of Population 2016 - Profile 2 Population Distribution and Movements. https://www.cso.ie/en/releasesandpublications/ep/p-cp2tc/cp2pdm/pd/ (accessed 2 November 2018).

Choi, D., Beardsley, M., Brzezinski, D., Koupal, J., Warila, J., 2010. MOVES sensitivity analysis: the impacts of temperature and humidity on emissions. In: Proceedings of the $19^{\text {th }}$ international emission inventory conference San Antonio, Texas.

Bell, K.E, Kothuri, S.M., Figliozzi, M.A., 2013. Emission model sensitivity analysis: The value of smart phone weight-mile tax truck data. European Trans., 54 (8). ISSN 1825-3997.

Demir, E., Bektas, T., Laporte, G., 2011. A comparative analysis of several vehicle emission models for road freight transportation. Transport. Res. Part D , 16, 347-357. DOI:10.1016/j.trd.2011.01.011

Department of Transport, Tourism and Sport (DTTAS), 2016. "Irish Bulletin of Vehicle and driver Statistics" DTTAS, February 16.

Department of Transport, Tourism and Sport (DTTAS), 2016. Common Appraisal Framework for Transport Projects and Programmes. Department of Transport, Tourism and Sport. 
Dey, S., Caulfield, B., Ghosh, B., 2017. The potential health, financial \& environmental impacts of dieselgate in Ireland. J. of Transport. Plan. and Technol., 41, 17-36. DOI: $10.1080 / 03081060.2018 .1402743$.

Dineen, D., Howley, M., Holland, M., 2014. Energy in Transport: 2014 Report, Sustainable Energy Authority of Ireland (SEAI).

Doorley, R., Pakrashi, V., Ghosh, B., 2015. Quantification of the Potential Health and Environmental Impacts of Active Travel in Dublin, Ireland. Transportation Research Record: Journal of the Transportation Research Board, 2531, 129-136.

Eggleston, S., Buendia, L., Miwa, K., Ngara, T., Tanabe, K., 2006. 2006 IPCC Guidelines for National Greenhouse Gas Inventories. Intergovernmental Panel on Climate Change.

EMISIA, 2014. COPERT Countries data, http://emisia.com/products/copert-data (accessed 20 April 16).

EMISIA, 2017. COPERT- Versions. http://emisia.com/products/copert/versions (accessed 05 December 2017).

Environmental Protection Agency (EPA), 2017. Ireland's Greenhouse Gas Emissions in 2015. http://www.epa.ie/pubs/reports/air/airemissions/ghgemissions/ (accessed 20 April 2017).

European Environmental Agency (EEA), 2014. Air pollution fact sheet 2014 - Ireland. https://www.eea.europa.eu/themes/air/air-pollution-country-fact-sheets-2014/ireland-air-pollutantemissions-country-factsheet/view (accessed 15 June 2017).

European Environmental Agency (EEA), 2015. Air Quality in Europe - 2015 report. EEA Report no. 5/2016. https://www.eea.europa.eu/publications/air-quality-in-europe-2015\#tab-data-references (accessed 16 June 2017).

European Environmental Agency (EEA), 2016. Air Quality in Europe - 2016 report. EEA Report no. 28/2016. https://www.eea.europa.eu/publications/air-quality-in-europe-2016 (accessed 16 June 2017).

European Environmental Agency (EEA), 2016. EMEP/EEA air pollutant emission inventory guidebook 2016. EEA technical report no 21/2016. http://www.eea.europa.eu/publications/emep-eeaguidebook-2016 (accessed 10 March 2017).

European Environmental Agency (EEA), 2016. Directive (Eu) 2016/2284 of the European Parliament and of the Council. Official Journal of the European Union.

Eurostat, 2014. Greenhouse gas emission statistics. http://ec.europa.eu/eurostat/statisticsexplained/index.php/Greenhouse_gas_emission_statistics (accessed 18 April 2017).

Fameli, K.M., Assimakopoulos, V.D., 2015. Development of a road transport emissions inventory for Greece and the Greater Athens Area: Effects of important parameters. Sci. of the Total Environ., 505, 770-786.

Garcia, J., Cerdeira, R., Tavares, N., Coelho, L.M.R., Carvalho, M.G., 2013. Sensitivity Analysis on Pm Traffic Emission Modeling Parameters. 15th International Conference on Harmonisation Within Atmospheric Dispersion Modelling for Regulatory Purposes, 6-9 May 2013, Madrid, Spain. DOI: $10.3141 / 2270-16$

Gkatzoflias, D., Kouridis, C., Ntziachristos, L., Samaras, Z., 2012. Computer programme to calculate emissions from road transport. User manual. COPERT 4.

Howley, M., Holland, M., Dineen, D., 2015. Energy in Ireland: Key Statistics 2015. Sustainable Energy Authority of Ireland (SEAI). 
Howley, M., Holland, M., 2016. Energy in Ireland 1990 - 2015. Sustainable Energy Authority of Ireland.

Kioutsioukis, I., Tarantola, S., Saltelli, A., Gatelli, D., 2004. Uncertainty and global sensitivity analysis of road transport emission estimates. Atmos. Environ. , 38, 6609-6620. DOI:10.1016/j.atmosenv.2004.08.006.

Kouridis, C., Gkatzoflias, D., Kioutsioukis, I., Ntziachristos, L., Pastorello, C., Dilara, P., 2010. Uncertainty Estimates and Guidance for Road Transport Emission Calculations. JRC Scientific and Technical Reports. European Commission Joint Research Centre Institute for Environment and Sustainability.

Kouridis, C., Mellios, G., Ntziachristos, L., 2014. COPERT 4 main elements. http://emisia.com/sites/default/files/COPERT_4_Statistics.ppt (accessed 18 April 2016).

Kousoulidou, M., Ntziachristos, L., Gkeivanidis, S., Samaras, Z., Franco, V., Dilara, P., 2010. Validation of the COPERT road emission inventory model with real-use data, Laboratory of Applied Thermodynamics, Dept. of Mechanical Engineering, Aristotle \& Institute for Environment and Sustainability, Transport and Air Quality Unit.

Loucks, D.P., Beek, E.V., Stedinger, J.R., Dijkman, J.P.M., Villars, M.T., 2005. Water Resources Systems Planning and Management. United Nations Educational, Scientific and Cultural Organization, UNESCO, ISBN 92-3-103998-9.

MET Eireann, 2016. Irish Weather reports for the year 2015. http:/www.met.ie/climate/irish-climatemonthly-summary.asp (accessed 25 November 2016).

MET Eireann, 2016. Monthly Data. http://www.met.ie/climate/monthly-data.asp (accessed 25 November 2016).

Notte, A.L., Tonin, S., Lucaroni, G., 2018. Assessing direct and indirect emissions of greenhouse gases in road transportation, taking into account the role of uncertainty in the emissions inventory. Environ. Impact Assess. Review, 69, 82-93. DOI:10.1016/j.eiar.2017.11.008

Ntziachristos, L., Zissis., S., 2014. Exhaust emissions from road transport. http://emisia.com/sites/default/files/1\%20A\%203\%20b\%20Road\%20transport\%20GB2014_latest.pdf

Ong, H.C., Mahlia, T.M.I., Masjuki, H.H., 2011. A review on emissions and mitigation strategies for road transport in Malaysia. Renew. Sustain. Energy Rev., 15, 3516-3522.

Pouliot, G., Pierce, T., van der Gon, H.D., Schaap, M., Moran, M., Nopmongcol, U., 2012. Comparing emission inventories and model-ready emission datasets between Europe and North America for the AQMEII project. Atmos. Environ. , 53, 4-14.

Road Safety Authority (RSA), 2015. Free Speed Study: Survey Report 2015. http://www.rsa.ie/en/RSA/Road-Safety/RSA-Statistics/Surveys--Consultations/Speed/ (accessed 02 March 2017).

Road Safety Authority (RSA), 2016. The Introduction of Euro 5 and Euro 6 Emissions Regulations for Light Passenger and Commercial Vehicles. http://www.rsa.ie/Documents/Vehicle\%20Std\%20Leg/Emissions\%20regs/Euro\%205\%20and\%20Eur o\%206\%20Emissions\%20Reg\%20light\%20passengercommvehicles.pdf

Ricardo- AEA, 2014. Update of the Handbook on External Costs of Transport, Report for the European Commission: DG MOVE. United Kingdom, January 8.

Saikawa, E., Trail, M., Zhong, M., Wu, Q., Young, C.L., Maenhout, G.J., Klimont, Z., Wagner, F., Kurokawa, J., Nagpure, A.S., Gurjar, B.R., 2017. Uncertainties in emissions estimates of greenhouse gases and air pollutants in India and their impacts on regional air quality. Environ. Res. Lett., 12, 065002. DOI:10.1088/1748-9326/aa6cb4 
Singh, R.B., Huber, A.H., Braddock, J.N., 2012. Sensitivity Analysis and Evaluation of MicroFacPM: A Microscale Motor Vehicle Emission Factor Model for Particulate Matter Emissions. J. of the Air \& Waste Manag. Assoc. 57, 420-433. DOI:10.3155/1047-3289.57.4.420.

Souza, C.D.R., Silva, S.D., Silva, M.A.V., D’Agosto, M.A., Barboza, A.P., 2013. Inventory of conventional air pollutants emissions from road transportation for the state of Rio de Janeiro. Energy Pol. 53, 125-135. DOI: 10.1016/j.enpol.2012.10.021.

Sustainable Energy Authority of Ireland (SEAI), 2013. Average Fuel Consumption and Distance Travelled for Private Cars by Engine Capacity cc, Type of Fuel, Year and Statistic. Energy statistics databank.

http://www.cso.ie/px/pxeirestat/statire/SelectVarVal/Define.asp?Maintable=SEI07\&PLanguage=0 (accessed 23 February 2017).

The Society of the Irish Motor Industry (SIMI), 2015. Motorstats, the official statistics of the Irish Motor Industry. http://www.beepbeep.ie/stats (accessed 19 April 2017).

The Society of the Irish Motor Industry (SIMI), 2016. Motorstats, The official statistics of the Irish Motor Industry. http://www.beepbeep.ie/stats (accessed 21 September 2016).

United States Environmental Protection Agency (USEPA), 2016. Learn About Volkswagen Violations. https://www.epa.gov/vw/learn-about-volkswagen-violations (accessed 16 August 2016).

United States Environmental Protection Agency (USEPA), 2017. Air Emissions Inventories. (accessed 02 June 2017).

Vanhulsel, M., Degraeuwe, B., Beckx, C., Vankerkom, J., Vlieger., I.D., 2014. Road transportation emission inventories and projections - Case study of Belgium: Methodology and pitfalls. Transport. Res. Part D , 27, 41-45. DOI: 10.1016/j.trd.2013.12.002

World Weather \& Climate Information, 2016. Weather Averages and Climate in Ireland. https://weather-and-climate.com/average-monthly-Rainfall-Temperature-Sunshine-in-Ireland (accessed 25 November 2016).

Yan, F., Winijkul, E., Bond, T.C., Streets, D.G., 2014. Global emission projections of particulate matter (PM): II. Uncertainty analyses of on-road vehicle exhaust emissions. Atmos. Environ., 87, 189199. DOI:10.1016/j.atmosenv.2014.01.045

Yao, Z., Wei, H., Perugu, H., Liu, H., Le, Z., 2014. Sensitivity analysis of project level MOVES running emission rates for light and heavy duty vehicles. J. of Traffic and Trans. Eng., 1(2), 81-96. 